ISSN 1979-5572 (print)

ISSN 2541-6480 (online

http://ejurnal.iainpare.ac.id/index.php/kuriositas

\title{
KURIOSITAS
}

Media Komunikasi Sosial dan Keagamaan

\begin{tabular}{lll}
\hline Volume 11 & No. 2, Desember 2018 & Halaman 111-121 \\
\hline
\end{tabular}

\section{APLIKASI AL KALAM DALAM MENINGKATKAN MOTIVASI MEMBACA AL-QURAN}

\author{
Muhammad Nur \\ SMPN 5 Duampanua \\ mnur@stainparepare.ac.id
}

\begin{abstract}
The purpose of this study was to determine the differences in the level of motivation to read the al-Qur'an by using the Al Kalam application on Alquran Writing and Reading subjects in SMP 5 Duampanua. The research used experimental research with treatment by level design technique, to analyze and tes the hypothesis of the author using the percentage and $\mathrm{T}$-assisted $\mathrm{t}$ tes version 21 with analysis of two-lane variants. According to the results of the study, there is a level of motivation to read the al-Qur'an by using the Al Kalam application based on the frequency of the percentage that the experimental class is in the high category. The implication shows that there are differences in the level of motivation to read the Koran using the Al Kalam application in the experimental class, compared to the level of motivation of students who do not use the $\mathrm{Al}$ Kalam application.
\end{abstract}

Keywords: Al Kalam application, motivation to read al-Qur'an, students.

\begin{abstract}
ABSTRAK
Tujuan penelitian ini adalah untuk mengetahui perbedaan tingkat motivasi membaca Alquran dengan menggunakan aplikasi Al Kalam pada mata pelajaran Baca Tulis Alquran di SMP Negeri 5 Duampanua. Penelitian ini menggunakan metode penelitian eksperimen dengan teknik treatment by level design. Untuk menganalisis, dan menguji hipotesis penulis menggunakan persentase dan uji $t$ berbantuan SPSS versi 21 dengan analisis varian dua jalur. Hasil penelitian menunjukkan bahwa terdapat perbedaan tingkat motivasi membaca Alquran menggunakan aplikasi Al Kalam pada kelas eksperimen, dibanding dengan tingkat motivasi peserta didik yang tidak menggunakan aplikasi Al Kalam.
\end{abstract}


Selain itu motivasi membaca Alquran dengan menggunakan aplikasi Al Kalam berdasarkan frekuensi persentase kelas eksperimen berada pada kategori tinggi.

Kata kunci: Aplikasi Al Kalam, motivasi membaca Alquran, peserta didik.

\section{PENDAHULUAN}

Perkembangan teknologi informasi, dan komunikasi semakin pesat pada era globalisasi. Perkembangan tersebut membawa perubahan dalam beberapa aspek kehidupan manusia, termasuk dalam bidang pendidikan. Kemajuan teknologi informasi, dan komunikasi telah banyak membantu dan mempermudah aktifitas dalam pelaksanaan pendidikan, baik bagi para pendidik, peserta didik maupun penyelenggara pendidikan.

Teknologi dalam pembelajaran sangat penting karena sudah merupakan kebutuhan untuk menambah informasi, meningkatkan kemampuan belajar, dan meningkatkan motivasi belajar. Informasi dan pengetahuan yang lebih lengkap serta akses yang mudah didapatkan dapat membuat peserta didik lebih termotivasi dalam melaksanakan pembelajaran. Penerapan teknologi dalam pendidikan memang memiliki beberapa manfaat untuk kelangsungan pembelajaran, namun di sisi lain harus tetap mengawasi peserta didik saat memanfaatkan teknologi karena mudahnya informasi yang mudah diakses melalui teknologi.

Sehubungan dengan itu sebagai pendidik berupaya mencari media yang tepat dalam proses belajar mengajar khususnya mata pelajaran Baca Tulis Alquran adalah dengan menggunakan media berupa aplikasi Al Kalam, hal ini dapat menunjukkan motivasi membaca dengan menggunakan pembelajaran berbasis aplikasi dan penerapannya jauh lebih baik daripada pembelajaran konvensional.

Oleh karena itu lebih khusus Pendidikan Agama Islam membutuhkan pembaharuan dalam mengikuti perkembangan ilmu pengetahuan dan teknologi dewasa ini, maka diharapkan dan lebih tepat bila diperkenalkan sebuah aplikasi bernama aplikasi Al Kalam. Penerapan aplikasi Al Kalam dalam proses pembelajaran adalah untuk mewujudkan kreativitas dan keterampilan membaca Alquran peserta didik serta untuk mendapatkan informasi terbaru dalam rangka mencari gagasan dalam membaca Alquran dengan baik dan benar.

Aplikasi Al Kalam dalam pembelajaran sangat bergantung pada kemampuan dan kesediaan pendidik untuk menggunakannya sebagai media dan sumber pembelajaran yang efektif. Oleh karena itu, setiap pendidik harus senantiasa bersedia untuk menghadapi tantangan teknologi informasi dan 
komunikasi yang semakin maju dan mempunyai komitmen untuk menggunakan media pembelajaran.

Salah satu komponen utama yang memegang peranan penting dalam pengajaran adalah pendidik, faktor pendidik sangat menentukan keberhasilan proses pembelajaran. Tugas pendidik adalah menyampaikan materi pembelajaran kepada peserta didik melalui interaksi komunikasi dalam pembelajaran yang dilakukan(Asnawir, 2002). Dengan intraksi yang baik peserta didik akan berilmu dan berakhlak.

Peserta didik dikatakan belajar dengan aktif, jika mereka berperan aktif dalam pembelajaran. Peserta didik secara aktif menggunakan otak, baik untuk menemukan ide pokok dari materi, memecahkan persoalan, atau mengaplikasikan apa yang dipelajari. Dalam Aktivitas pembelajaran, bukan hanya peserta didik yang aktif belajar tetapi dilain pihak, pendidik juga harus mengorganisasi suatu kondisi yang dapat mengaktifkan peserta didik dalam belajar.(Hamalik, 2000) Oleh karena itu, salah satu usaha yang dapat dilakukan pendidik Pendidikan Agama Islam adalah menggunakan aplikasi Al Kalam yang dapat memotivasi peserta didik agar belajar membaca Alquran secara aktif, baik dan benar.

Pada proses pembelajaran di sekolah termasuk pendidikan Agama Islam di harapkan melaksanakan program pemerintah tentang gerakan literasi sekolah yang merupakan wujud penumbuhan budi pekerti sebagaimana yang tercantum dalam Praturan Menteri Pendidikan dan Kebudayaan Republik Indonesia Nomor 23 Tahun 2013.(Sutrianto, Rahmawan, Hadi, \& Fitriono, 2016) Program literasi sekolah adalah kesempatan bagi pendidik Pendidikan Agama Islam menggunakan waktu 5 sampai dengan 15 menit membaca Alquran sebelum masuk pelajaran inti. Disamping itu pula kesempatan peserta didik membaca Alquran pada mata pelajaran muatan lokal Baca Tulis Alquran yang merupakan rumpun mata pelajaran Pendidikan Agama Islam yang dapat membantu dalam meningkatkan motivasi membaca Alquran perta didik SMP Negeri 5 Duampanua.

\section{METODE}

Jenis penelitian ini adalah penelitian eksperimen Gay, Geoffrey, Mills dan Peter Airasian mengemukakan sebagai berikut.

In experimental research manipulates at least one independent variable, controls other relevan variables, and observes the effect on one or more dependent variables. An experiment typically involves a comprarison of two groups (although some axperimental studies have only one group or even three or more groups).(Mills \& Gay, 2016) 
Penelitian eksperimental memanipulasi setidaknya satu variabel independen, mengontrol variabel lain yang relevan, dan mengamati efek pada satu atau lebih variabel tergantung. Sebuah percobaan biasanya melibatkan perbandingan dua kelas (meskipun beberapa penelitian eksperimental hanya memiliki satu kelas atau bahkan tiga atau lebih kelas).

Penelitian eksperimen merupakan metode inti dari model penelitian yang menggunakan desain kuantitatif.(Pd, 2010)

Penelitian eksperimen yang digunakan adalah Quasi Experimental Design adalah bentuk eksperimen yang merupakan pengembangan true experimental desain, hanya kelebihan eksperimen quasi adalah tidak memisahkan kelas yang sudah ada.(Sugiyono, 2016) Adapun gambar desain yang digunakan adalah nonequivalent control group design yang kelas eksperimen maupun kelas konrol tidak dipilih secara rondum.(Sugiyono, 2016). Diberikan pretes pada kelas eksperimen dan kelas kontrol, kemudian perlakuan/treatment berupa penggunaan aplikasi Al Kalam pada kelas eksperimen, selanjutnya melakukan posttes pada kelas eksperimen dan kelas control untuk membandingkan tingkat motivasi membaca Alquran dengan menggunakan aplikasi Al Kalam dengan yang tidak menggunakan aplikasi Al Kalam.

\section{PEMBAHASAN}

Pada penelitian ini, aplikasi Al Kalam memiliki peranan sangat penting guna meningkatkan motivasi membaca Alquran. Selama pemberian perlakuan, penulis mengamati dan menyajikan materi perulangan membaca Alquran menggunakan aplikasi Al Kalam dan dilengkapi dengan latihan-latihan mengenal hukum bacaan dalam ilmu tajwid.

Motivasi merupakan daya yang mendorong seseorang baik secara sadar maupun tidak, yang memunculkan, mengarahkan, dan mempertahankan perilaku untuk melakukan sesuatu dalam rangka mencapai tujuan tertentu.(RIZAL, 2015) Bila peserta didik ingin memperoleh keberhasilan dalam studi. Maka langkah awal yang harus dimiliki adalah adanya motivasi dalam diri peserta didik yang merupakan faktor terpenting untuk meningkatkan prestasi belajar, karena kalau hal ini lemah maka aktivitas peserta didik menjadi lemah pula. Motivasi lain juga dapat timbul atau dipengaruhi oleh adanya stimulus dari luar, dalam hal ini stimulus tersebut adalah aplikasi Al Kalam pembelajaran baca tulis Alquran .

Oleh karena itu dapat dikemukakan bahwa penggunaan aplikasi Al Kalam dalam proses pembelajaran dapat membangkitkan motivasi yang baru dan hal ini merupakan teori baru, membangkitkan motivasi dan rangsangan membaca Al- Quran. Aplikasi Al Kalam memiliki peranan penting dalam mata 
pelajaran baca tulis Alquran dan banyak memberikan manfaat. Peranan aplikasi Al Kalam dalam pembelajaran diantaranya adalah menumbuhkan motivasi peserta didik ketika mengikuti proses pembelajaran, adanya interaksi langsung antara anak didik dengan menggunakan teknologi.

Selanjutnya penggunaan aplikasi Al Kalam sebagai bagian integral dalam pembelajaran antara lain yaitu penyampaian materi menjadi lebih baku, lebih menarik, serta pembelajaran jadi lebih efesien dan efektif. Senada dengan itu, dapat pula dikemukakan manfaat pembelajaran aplikasi Al Kalam dalam proses pembelajaran peserta didik, antara lain adalah dengan tampilan yang menarik akan lebih menumbuhkan motivasi peserta didik, makna materi yang disampaikan lebih jelas dan lebih mudah dipahami oleh peserta didik, dengan media ini peserta didik tidak bosan dan pendidik tidak kehabisan tenaga karena dalam proses pembelajaran pendidik tidak terus menerus menggunakan komunikasi verbal. kegiatan belajar akan lebih banyak dilakukan oleh peserta didik sebab tidak hanya melihat dan mendengarkan proses dalam aplikasi Al Kalam lagi pula peserta didik dapat mengamati dan melakukannya melalui latihan-latihan.

Aplikasi Al Kalam dalam pembelajaran baca tulis Alquran merupakan salah satu aplikasi yang dapat digunakan, karena merupakan aplikasi yang populer dan digemari karena sifatnya menarik perhatian, serta memiliki keunikan pada tulisan dan audionya. Sehingga sangat baik bila digunakan sebagai media pembelajaran membaca Alquran.

Berdasarkan analisis di atas maka dapat disimpulkan bahwa penggunaan aplikasi Al Kalam dalam pembelajaran baca tulis Alquran, dapat meningkatkan motivasi membaca Alquran dalam proses pembelajaran. Berikut ini akan dijelaskan mengenai motivasi belajar peserta didik mengikuti proses pembelajaran pada kelas eksperimen dan kelas kontrol:

\section{Antusias tinggi}

Antusias tinggi merupakan ciri-ciri dari peserta didik yang memiliki motivasi mengikuti proses pembelajaran baca tulis Alquran . Peserta didik yang memiliki motivasi mengikuti proses pembelajaran baca tulis Alquran seharusnya ditunjukkan dengan keyakinan yang kuat dari peserta didik untuk mendapat nilai yang tinggi pada proses pembelajaran baca tulis Alquran . Hasil penelitian dari aspek antusias menunjukkan bahwa pada kelas kontrol diperoleh hasil rendah. Hal ini menunjukkan bahwa peserta didik kurang memiliki antusias dalam mengikuti proses pembelajaran baca tulis Alquran. Hal tersebut ditunjukkan melalui hasil tes motivasi yang menunjukkan bahwa peserta didik kurang memiliki semangat membaca Alquran. Sementara itu, pada kelas 
eksperimen setelah diberi perlakuan penggunaan aplikasi Al Kalam pembelajaran baca tulis Alquran, diperoleh hasil posttes yang tinggi, hal tersebut terlihat dari kegiatan peserta didik dalam proses pembelajaran yang berkeyakinan kuat untuk mendapat semangat membaca Alquran pada proses pembelajaran baca tulis Alquran dengan menggunakan aplikasi Al Kalam.

\section{Mengendalikan perhatian dan energinya pada proses pembelajaran}

Pengendalian perhatian, dan energi merupakan ciri-ciri peserta didik yang memiliki motivasi mengikuti proses pembelajaran baca tulis Alquran . Peserta didik yang memiliki motivasi mengikuti proses pembelajaran baca tulis Alquran yang seharusnya ditunjukkan dengan perhatian yang tinggi pada proses pembelajaran, tidak jalan-jalan di kelas saat pendidik menjelaskan materi ajar dan tidak membuat keributan di kelas saat pendidik memberi tugas latihan membaca Alquran. Berdasarkan hasil penelitian pada kelas kontrol diperoleh hasil yang berbeda dengan harapan tersebut. Hal ini menunjukkan bahwa peserta didik kurang mengendalikan perhatian dan energinya mengikuti proses pembelajaran baca tulis Alquran. Hal tersebut ditunjukkan melalui hasil tes motivasi yang menunjukkan bahwa peserta didik tidak dapat mempertahankan perhatian dalam proses pembelajaran, jalan-jalan di kelas dan membuat keributan di kelas. Sementara itu, pada kelas eksperimen setelah diberi perlakuan penggunaan aplikasi Al Kalam pembelajaran baca tulis Alquran, diperoleh hasil posttes yang tinggi. Hal tersebut dapat dilihat pada kegiatan peserta didik dalam proses pembelajaran yang mempertahankan perhatian dan energinya dalam proses pembelajaran, tidak lagi jalan-jalan di kelas saat pendidik menjelaskan materi ajar dan tidak membuat keributan di kelas.

\section{Tekun menghadapi tugas dalam proses pembelajaran}

Tekun mengerjakan tugas merupakan ciri-ciri peserta didik yang memiliki motivasi belajar yang tinggi. Motivasi peserta didik mengikuti proses pembelajaran baca tulis Alquran seharusnya ditunjukkan dengan kemudahan peserta didik dalam mengerjakan tugas. Namun kelas kontrol diperoleh hasil yang berbeda dari harapan tersebut dan diperoleh hasil rendah. Hal ini menunjukkan bahwa peserta didik kurang tekun dalam mengerjakan tugas karena terlalu sulit. Hal tersebut ditunjukkan melalui hasil tes motivasi yang menunjukkan bahwa peserta didik merasa kesulitan dalam mengerjakan tugastugas latihan sehingga mereka enggan untuk mengerjakan tugas tersebut. Sementara itu, setelah diberi perlakuan penggunaan aplikasi Al Kalam pembelajaran baca tulis Alquran, diperoleh hasil posttes yang sangat tinggi. Hal tersebut terlihat pada kegiatan peserta didik dalam proses pembelajaran yang 
sudah tidak terlalu sulit lagi dalam mengerjakan tugas-tugas latihan dalam proses pembelajaran baca tulis Alquran .

Senang dan rajin belajar, penuh semangat, tidak cepat bosan dengan tugas-tugas rutin, dapat mempertahankan pendapat merupakan ciri-ciri peserta didik yang memiliki motivasi belajar yang tinggi. Peserta didik yang memiliki motivasi belajar yang tinggi pada mata pelajaran baca tulis Alquran model pembelajaran Student Team Achievment Division Student Team Achievment

Pelaksanaan Model Pembela Alquran seharusnya ditunjukkan dengan semangat dengan jumlah pengulangan materi pembelajaran, tidak mengantuk ketika pendidik menampilkan materi pelajaran, dan tidak tidur di kelas saat pendidik menampilkan materi ajar. Namun kelas kontrol diperoleh hasil yang berbeda dari ciri-ciri tersebut dan diperoleh hasil rendah. Hal ini menunjukkan bahwa peserta didik kurang semangat dalam mengikuti proses pembelaajaran. Hal tersebut ditunjukkan melalui hasil tes motivasi yang menunjukkan bahwa peserta didik merasa bosan dengan jumlah pengulangan materi ajar. Namun kelas eksperimen setelah diberi perlakuan penggunaan aplikasi Al Kalam pembelajaran baca tulis Alquran, diperoleh hasil posttes yang tinggi. Hal tersebut dapat dilihat pada kegiatan proses pembelajaran baca tulis Alquran yang sudah tidak bosan lagi dengan latihan-latihan, tidak lagi mengantuk ketika pendidik menampilkan media pembelajaran aplikasi Al Kalam.

\section{Motivasi Ekstrinsik}

\section{Tertarik pada aplikasi Al Kalam pembelajaran baca tulis Alquran artinya tidak acuh tak acuh.}

Tertarik pada aplikasi Al Kalam pembelajaran baca tulis Alquran artinya peserta didik termotivasi belajar saat pendidik menggunakan aplikasi Al Kalam tersebut. Perpaduan antara tulisan yang berwarna dan audio pada aplikasi Al Kalam dapat memicu semangat dan motivasi peserta didik dalam mengikuti proses pembelajaran baca tulis Alquran. Dari hasil kelas kontrol diperoleh diperoleh bahwa peserta didik kurang termotivasi dan masuk dalam kategori rendah. Dari hasil tersebut menunjukkan bahwa kurangnya kesadaran peserta didik dalam mengambil manfaat pada yang ada dalam materi pelajaran, tidak tertarik dengan bacaan-bacaan Alquran, kurang semangat membaca materi baca tulis Alquran, sebagaian besar materi tajwid tidak dipahami sehingga motivasi untuk tahu materi selanjutnya berkurang. Oleh karena itu, penulis berusaha untuk membuat peserta didik termotivasi dengan menerapkan aplikasi Al Kalam yang digunakan dalam proses pembelajaran baca tulis Alquran. Penulis melakukan perlakuan berupa penggunaan aplikasi Al Kalam pembelajaran baca tulis Alquran. Hal tersebut meningkatkan motivasi belajar peserta didik yang 
terlihat pada hasil kelas ekasperimen yang tinggi. Hasil tersebut dapat ditunjukkan bahwa peserta didik dapat termotivasi dan mengambil manfaat pada mata pelajaran baca tulis Alquran .

\section{Tertarik pada mata pelajaran yang diajarkan.}

Mata pelajaran baca tulis Alquran adalah mata pelajaran penting untuk pelajaran membaca Alquran, untuk memberi motivasi peserta didik agar semangat belajar materi baca tulis Alquran yaitu dengan menggunakan aplikasi Al Kalam yang menarik dan mudah dipahami oleh peserta didik. Namun pada hasil tes kelas kontrol yang dilakukan oleh penulis menunjukkan hasil yang rendah terhadap materi yang disajikan pendidik pada proses pembelajaran. Pada kelas kontrol menunjukkan bahwa peserta didik kurang termotivasi mengikuti pelajaran baca tulis Alquran, tidak dapat mengambil manfaat pada mata pelajaran yang diajarkan dan keinginan kurang dalam mengikuti mata pelajaran baca tulis Alquran. Dalam hal ini penulis menyajikan materi ajar baca tulis Alquran dengan menarik dan mudah dipahami oleh peserta didik, hal ini terlihat pada hasil posttes kelas eksperimen tinggi. Hal tersebut menunjukkan bahwa setelah dilakukan perlakuan maka peserta didik memiliki keinginan tinggi dalam mengikuti pelajaran baca tulis Alquran, mengambil manfaat dari cerita yang ada dalam materi ajar dan termotivasi untuk ikut belajar baca tulis Alquran.

\section{Variasi aktivitas belajar lebih banyak}

Variasi aktivitas belajar lebih banyak berarti peserta didik memperoleh informasi belajar yang lebih, sehingga peserta didik lebih kreatif dalam mencari informasi belajar. Hasil pretes kelas kontrol menunjukkan bahwa peserta didik kurang memiliki motivasi, karena cara pendidik kurang tidak menggunakan media, materi ajar yang disampaikan sangat monoton, pendidik layaknya seperti penceramah dan kurang komunikatif. Namun setelah diberi perlakuan, hasil posttes kelas eksperimen menunjukkan adanya peningkatan dari sebelum diberi perlakuan dan termasuk dalam kategori tinggi. Bila dalam kelas ditunjukkan aktivitas belajar lebih banyak dan bukan hanya mendengarkan penjelasan dari pendidik melainkan peserta didik mencatat hal penting dan menyiapkan pertanyaan untuk diajukan kepada pendidik.

Perkembangan motivasi belajar peserta didik mengikuti proses pembelajaran baca tulis Alquran juga ditunjukkan berdasarkan analisis deskriptif yang menunjukkan bahwa ada perbedaan antara kelas kontrol tidak diberi perlakuan dan dibanding kelas eksperimen sesudah diberi perlakuan. Berdasarkan analisis tersebut peserta didik mengalami peningkatan motivasi 
belajar membaca Alquran dengan menggunakan aplikasi Al Kalam pada pembelajaran baca tulis Alquran .

Pada dasarnya adanya perbedaan menggunakan aplikasi dengan tidak menggunakan aplikasi berarti aplikasi Al Kalam bermanfaat peserta didik dan bermanfaat bagi pendidik maka dapat dikatakan bahwa aplikasi Al-Kalam adalah pembelajaran menjadi lebih efektf dan efisian dengan lancarnya interaksi antara pendidik dengan peserta didik. Sedangkan secara lebih khusus manfaatnya dalam pembelajaran bahwa dengan bantuan aplikasi Al Kalam, dapat dihindari dan dapat mengurangi informasi dari peserta didik bacaan yang salah dan yang benar. Dengan aplikasi Al Kalam dapat menampilkan informasi melalui suara, tulisan warna sehingga membantu pendidik untuk dapat lebih menghidupkan suasana pamebelajaran yang tidak monoton dan membosankan. Dengan aplikasi Al Kalam terjadinya komukasi dua arah secara aktif, sedangkan tanpa media pendidik cenderung bicara satu arah. Dengan Aplikasi Al Kalam tujuan belajar akan lebih mudah tercapai secara maksimal dengan waktu dan tenaga seminimal mungkin. Pendidik tidak harus menjelaskan materi ajaran secara berulang-ulang pada materi yang sama, sebab dengan sekali sajian menggunakan media, peserta didik akan lebih mudah memahami pelajaran. Dengan aplikasi Al Kalam pembelajaran dapat membantu peserta didik menyerap materi belajar lebih mandalam dan utuh. Bila dengan mendengar informasi verbal dari pendidik saja, peserta didik kurang memahami pelajaran, tetapi jika diperkaya dengan kegiatan melihat, mencoba, merasakan dan mengalami sendiri melalui media pemahaman peserta didik akan lebih baik. Dengan aplikasi Al Kalam proses pembelajaran menjadi lebih menarik sehingga memberi motivasi peserta didik untuk megulangi materi pelajaran yang diberikan. Dengan aplikasi Al Kalam pendidik dapat berbagi peran dengan media sehingga banyak mamiliki waktu untuk memberi perhatian pada aspekaspek edukatif lainnya, seperti membantu kesulitan belajar peserta didik, pembentukan kepribadian, memberi motivasi membaca Alquran, dan lain-lain.

Penelitian ini hanya mengontrol tingkat motivasi belajar peserta didik, sehingga tidak tertutup kemungkinan adanya pengaruh variable-variabel yang lain seperti, minat peserta didik, kreativitas peserta didik dan lain-lain. Selain itu, kelompok perlakuan berada pada jadwal yang berbeda dengan yang tidak diberi perlakuan sehingga tidak tertutup kemungkinan ada saling komunikasi dengan kelas kontrol dengan kelas eksperimen. Teknik pengambilan data pretes dan posttes bersamaan, ada kemungkinan untuk saling komunikasi mendapatkan jawaban sama. 


\section{SIMPULAN}

Tingkat motivasi membaca Alquran peserta didik mengikuti proses pembelajaran mulok baca tulis Alquran sebelum diberi perlakuan kelas eksperimen dan kelas kontrol berupa penggunaan aplikasi Al Kalam dapat dilihat frekuensi persentase bahwa kelas eksperimen $68.71 \%$ dan kelas kontrol $64.01 \%$ sebelum diperlakukan keduanya berada pada ketegori rendah.

Tingkat motivasi membaca Alquran peserta didik SMP Negeri 5 Duampanua mengikuti proses pembelajaran mulok baca tulis Alquran sesudah diberi perlakuan berupa penggunaan aplikasi Al Kalam kelas eksperimen adalah dikategorikan tinggi mencapai rata-rata dari semua indikator motivasi 87,62 \%, kelas kontrol tidak diperlakukan $69.52 \%$ berada pada kategori rendah, berarti mengalami peningkatan, yang berarti ada perbedaan tingkat motivasi kelas kontrol yang tidak diperlakukan dengan kelas eksperimen yang telah diperlakukan. Sedangkan perbedaan motivasi belajar membaca Alquran antara kelas eksperimen sebelum dan sesudah diperlakukan terdapat perbedaan 18,91 $\%$.

Senada dengan hal diatas uji hipotesis sebelum deperlakukan kelas eksperimen dengan kelas kontrol menyatakan $t$ hitung 1,226 $<\mathrm{t}$ tabel 2,021, maka $\mathrm{t}$ hitung terletak pada daerah $\mathrm{H} 0$ diterima, dan berdasarkan perbandingan nilai probabilitas (sig), probabilitas 0,224 >0,050, maka H0 diterima, berarti tidak ada perbedaan tingkat motivasi pada dua kelas sebelum diperlakukan. Akan tetapi setelah diperlakukan kelas eksperimen dengan kelas kontrol menunjukkan hasil t hitung $9.577>\mathrm{t}$ tabel 2,021, maka t hitung terletak pada daerah $\mathrm{H} 0$ ditolak, dan berdasarkan perbandingan nilai probabilitas (sig), probabilitas 0,000<0,050, maka $\mathrm{H} 0$ ditolak. Ini berarti terdapat perbedaan tingkat motivasi membaca Alquran menggunakan aplikasi Al Kalam pada kelas eksperimen, dibanding dengan tingkat motivasi peserta didik yang tidak menggunakan aplikasi Al Kalam. Disimpulkan bahwa dengan menggunakan aplikasi Al Kalam terdapat perbedaan antara kelas kontrol dengan kelas eksperimen dalam meningkatkan motivasi membaca Alquran .

\section{REFERENCE}

(1) Asnawir, B. U. (2002). Media Pembelajaran. Jakarta: Ciputat Perss.

(2) Hamalik, O. (2000). Psikologi Belajar dan Mengajar. PT Sinar Baru Algensindo.

(3) Kunandar. GURU PROFESIONAL. Bandung: Raja Grafindo Persada, 2009.

(4) Mulyadi. Kepemimpinan Kepala Sekolah dalam Mengembangkan Budaya Mutu. Cet. I, Malang: UIN-maliki press, 2010. 
(5) Mulyasa. Manajemen Berbasis Sekolah. Bandung: Remaja Rosda Karya, 2002.

(6) Munaris. Metode Penelitian (Suatu Pendekatan Proposal). Jakarta: Bumi Aksara, 2000.

(7) Munir, Abdullah. Menjadi Kepala Sekolah Efektif, Cet. III. Malang: ArRuzz Media, 2010.

(8) Noor, Juliansyah. Metodologi Penelitian: Skripsi, Tesis, Disertasi dan Karya Ilmiah Edisi Pertama. Jakarta: Kencana Prenada Media Group, 2011.

(9) Nurdi. "Peran Kepemimpinan Kepala Madrasah dalam Mengembangkan Profesionalisme Guru di SMA Unggulan BPPT Al-Fatah Lamongan". Tesis tidak diterbitkan: program pascasarjana UIN Malang, 2010.

(10) Pawito. Penelitian Komunikasi Kualitatif. Yogyakarta: PT. LKIS Pelangi Aksara, 2007.

(11) Mills, G. E., \& Gay, L. R. (2016). Educational Research: Competencies for Analysis and Applications. Pearson Upper Saddle Ridge, NJ.

(12) Pd, T. (2010). Pengantar Penelitian Pendidikan bagi Pengembangan Profesi Pendidikan \& Tenaga Kependidikan. Jakarta: Kencana Prenada Media Group.

(13) Rizal, A. A. F. (2015). Hubungan Pelaksanaan Fungsi Manajemen Kepala Ruang dengan Motivasi Perawat Pelaksana dalam Memberikan Layanan Keperawatan di Ruang Rawat Inap RSUD Kota Semarang. UNDIP.

(14) Sugiyono, P. D. (2016). Metode penelitian pendidikan. Pendekatan Kuantitatif.

(15) Sutrianto, S., Rahmawan, N., Hadi, S., \& Fitriono, H. (2016). Panduan Gerakan Literasi Sekolah Di Sekolah Menengah Atas. Direktorat Pembinaan Sekolah Menengah Atas Direktorat Jenderal Pendidikan Dasar dan Menengah. 